\title{
PEMUKIMAN HYVE: KEHIDUPAN KOLEKTIF UNTUK MILENIAL
}

\author{
Rainier Lazar Hadiprodjo ${ }^{1)}$, Martin Halim²) \\ 1)Program Studi S1 Arsitektur, Fakultas Teknik, Universitas Tarumanagara, hrainierlazar21@gmail.com \\ ${ }^{2)}$ Program Studi S1 Arsitektur, Fakultas Teknik, Universitas Tarumanagara, martinhalim90@gmail.com
}

\begin{abstract}
Abstrak
Generasi milenial memiliki peluang dan kesempatan berinovasi yang sangat luas dan besar di era ini. Oleh karena itu, generasi milenial ini adalah modal besar untuk mewujudkan kemandirian bangsa dalam segala aspek. Saat ini jumlahnya sekitar $30 \%$ dari total penduduk Indonesia dan diperkirakan akan terus bertambah. Diprediksi generasi milenial akan sulit memiliki rumah dalam beberapa tahun ke depan. Ditambah lagi dengan terjadinya pandemi yang membatasi pergerakan masyarakat. Oleh karena itu diperlukan dilakukan penelitian mendalam terhadap kebutuhan ruang yang sangat dibutuhkan bagi para kaum milenial, sehingga dapat menciptakan parameter baru pada hunian yang dikhususkan bagi kaum milenial yang memiliki preferensi serba fleksibel dan praktis. Project "The Hyve Settlement" bertujuan untuk menghadirkan hunian yang efisien serta terjangkau bagi kaum Milenial. Dengan menghadirkan hunian modul unit, serta dilengkapi dengan furniture yang fleksibel dan compact sehingga meningkatkan space efficiency pada hunian. Serta menghadirkan communal living space untuk meningkatkan efisiensi ruang dan juga menciptakan social development terhadap penghuni lainnya. Menghadirkan program penunjang layaknya fasilitas umum untuk meningkatkan kualitas hidup para penghuni.
\end{abstract}

Kata kunci: Efisien, Fleksibel, Hunian, Kolektif, Milenial

\begin{abstract}
The millennial generation has a very wide and large opportunity and opportunity to innovate in this era. Therefore, this millennial generation is a great asset to realize national independence in all aspects. Currently the number is around $30 \%$ of the total population of Indonesia and is expected to continue to grow. It is predicted that the millennial generation will find it difficult to own a home in the next few years. Coupled with a pandemic that limits the movement of people. Therefore it is necessary to carry out in-depth research on the space requirements that are very much needed for millennials, so that they can create new parameters for housing specifically for millennials who have flexible and practical preferences. "The Hyve Settlement" project aims to provide efficient and affordable housing for Millennials. By presenting residential module units, and equipped with flexible and compact furniture so as to increase the space efficiency of the residence. As well as presenting communal living space to increase space efficiency and also create social development for other residents. Presenting supporting programs like public facilities to improve the quality of life for residents.
\end{abstract}

Keywords: Collective, Dwelling, Efficieny, Flexibelity, Millenial 


\section{PENDAHULUAN}

\section{Latar Belakang}

Generasi milenial memiliki peluang dan kesempatan berinovasi yang sangat luas dan besar di era ini. Oleh karena itu, generasi milenial ini adalah modal besar untuk mewujudkan kemandirian bangsa dalam segala aspek. Generasi milenial merupakan generasi yang lahir pada tahun 1980 sampai awal 2000-an. Saat ini jumlahnya sekitar 30 persen dari total penduduk Indonesia dan diperkirakan terus bertambah, dan dapat diprediksi generasi milenial akan sulit memiliki rumah atau terancam jadi 'gelandangan' dalam beberapa tahun ke depan.

Faktor lainnya, generasi milenial saat ini gaya hidupnya terbilang boros. Mereka lebih mementingkan gaya hidup ketimbang membeli rumah, seperti ingin terus mempunyai smartphone terbaru dan hobi travelling yang menghabiskan uang cukup besar. Sedikit dari mereka yang sadar akan kebebasan finansial dan lebih cenderung untuk mengikuti trend yang ada. Generasi milenial ini tertarik dengan rumah yang sederhana, namun memiliki fleksibilitas yang tinggi, fleksibilitas merujuk pada satu ruang yang dapat menampung berbagai aktivitas layaknya ruang istirahat dapat dijadikan sebagai ruang bekerja, dst. Di tahap awal membeli rumah, generasi milenial tak akan ambil pusing soal ukuran. Selama bisa ditempati, desain cukup, dan bisa memenuhi kebutuhan di rumah, maka sudah memenuhi demand generasi milenial. Berbeda dengan generasi sebelumnya yang lebih menyukai hunian dengan ukuran tanah yang luas, milenial justru lebih memilih konsep micro housing dan compact housing. Mereka lebih memilih mengeluarkan dana lebih untuk fungsi ruang dibandingkan tanah yang luas.

Berdasarkan persentase data kependudukan milenial, Jakarta Barat memiliki persentase yang paling tinggi di antara daerah Jakarta lainnya, dan berdasarkan persentase pengeluaran keluarga milenial didapati masih memiliki pengeluaran yang berlebihan pada sektor makanan dan perumahan, maka dari itu Arsitektur harus menanggapi perkembangan tersebut dengan tujuan membantu dan mendorong generasi muda ini agar dapat menjadi generasi yang dapat menjadi pemaju dan penerus bangsa demi menciptakan bangsa Indonesia yang mandiri dan kedepan di masa yang akan datang.

\section{Rumusan Permasalahan}

Kaum milenial kesulitan untuk mendapatkan hunian di tengah perkotaan yang dikarenakan tidak sebandingnya kenaikan upah dan kenaikan harga serta gaya hidup kaum milenial yang cenderung boros, sehingga memerlukan karakteristik kebutuhan hunian bagi milenial yang ideal.

\section{Tujuan}

Menghadirkan hunian terjangkau di tengah perkotaan yang berkelanjutan bagi milenial kini dan masa depan. Menciptakan hunian yang efisien dan menyediakan program kegiatan yang mampu memenuhi kebutuhan bagi para kaum milenial.

\section{KAJIAN LITERATUR}

\section{Dwelling menurut Etimologi}

Kata Dwelling dalam bahasa Inggris kunonya adalah "dwellan" yang berarti mengembara (to wander) dan bertahan hidup (to linger). Secarea filosofis, kata dwelling memberikan makna bahwa: "Untuk bertahan hidup, tidak dapat dilakukan dengan berdiam diri atau menetap tetapi harus mengembara".

\section{Dwelling menurut Martin Heidegger}

Dwelling adalah karakter dari sesuatu yang "ada", aberelasi dengan manusia di dunia. "Ada" disebut sebagai penyebab segala sesuatu yang ada, "Ada" merupakan tempat "beradanya". "Dasein" dan "das Seiende". "Ada" merupakan satu "peristiwa" yang menyebabkan beradanya segala sesuatu (van Peursen, 1980:96). Segala sesuatu yang "Ada" berdiri di depan horizonnya. Dengan demikian "Ada" dan "Waktu" saling berkaitan (van Peursen, 1980:245). Tinggal di rumah, tidak hanya berada di dalamnya secara spasial dalam arti hanya menyisir dan berputar dalam lingkungan rumah saja. 
Sebaliknya, rumah sebagai sesuatu yang "Ada" adalah milik dunia, dan orang yang menghuni didalamnya harus keluar untuk melihat "langit-langit dunia". Kata lama dari "Bauen" To build, dwell, also to care for, cherish, protect, preserve, nurture.

\section{Dwelling menurut Christian Norberg Schulz}

To dwell, berarrti pembentukkan hubugnan antara manusia dan lingkungan tertentu. Manusia menemukan dirinya ketika menetap, dan keberadaannya di dunia dengan demikian ditentukkan. Di sisi lain, manusia juga seorang pengembara. Terdapat 4 mode dwelling yaitu; The settlement, Urban Space, Institution (Public Dwelling) dan House (Private Dwelling).

\section{Kesimpulan Dwelling}

Manusia terlempar pada dunia tanpa memilih, dalam keberadaannya menuju kepada kematian. Manusia dalam menjalani hidupnya berkaitan dengan $d$ welling. Fenomena dwelling merupakan proses dimana manusia berusaha untuk bertahan hidup (survival) dengan kondisi geografis ataupun ancaman lainnya sehingga berkaitan erat dengan arsitektur. Hal ini berubah menjadi budaya, dan habit. Awal mula $d$ welling berasal dari sebuah shelter untuk bertahan hidup, kemudian perlahan-lahan $d$ welling berubah menjadi ruang untuk manusia berkumpul bersama untuk melakukan kegiatan tertentu.

\section{Milenial}

Millennial adalah istilah cohort dalam demografi, merupakan kata benda yang berarti pengikut atau kelompok. Saat ini ada empat cohort besar dalam demografi, yaitu Baby Boomer (lahir pada tahun 1946-1964), Gen-X (lahir pada tahun 1965-1980), Millennial (lahir pada tahun 1981-2000), dan Gen-Z (lahir pada tahun 2001-sekarang). Generasi milenial saat ini gaya hidupnya terbilang boros. Mereka lebih mementingkan gaya hidup ketimbang membeli rumah, seperti ingin terus mempunyai smartphone terbaru dan hobi traveling yang menghabiskan uang cukup besar. Sedikit dari mereka yang sadar akan kebebasan finansial dan lebih cenderung untuk mengikuti trend yang ada. Generasi milenial ini tertarik dengan rumah yang sederhana, namun memiliki fleksibilitas yang tinggi, fleksibilitas merujuk pada satu ruang yang dapat menampung berbagai aktivitas layaknya ruang istirahat dapat dijadikan sebagai ruang bekerja, dst.

\section{Everydayness}

Dasein secara harafiah berasal dari da-sein, yaitu being-there: ada-disana. Dasein sudah selalu beingin-the-world (sudah-selalu-bermukim-dalam-dunia). la sudah selalu 'ada-disana' semenjak ia menyadari bahwa dirinya ada, hadir ke dunia. Dasein berciri 'kemungkinan' (seinkönnen) dan 'khas' (jemeinigkeit). Dasein selalu berelasi melalui modus-modus tertentu, suatu cara mengada, cara menjadi dirinya. Dalam rangka menjadi dirinya sendiri, Dasein berusaha memahami dirinya sendiri (always understanding itself), itulah yang disebut dengan cara berada (bereksistensi). Karena Dasein merupakan suatu kemungkinan (seinkönnen), maka ia mempunyai kemungkinan menjadi dan tidak menjadi (possibility to be itself or not to be itself). "Keseharian" (everydayness) dalam kaitannya dengan Dasein berarti "setiap hari" (each day). Keseharian yang bertautan dengan Temporalitas. Keseharian ini tidak identik dengan hari dalam artian pagi, siang, malam, hingga pagi lagi. Dengan kata lain, keseharian tidak dimaknai dalam waktu kalender.

\section{Perumahan}

Secara fisik perumahan merupakan sebuah lingkungan yang terdiri dari kumpulan unit-unit rumah tinggal dimana dimungkinkan terjadinya interaksi sosial diantara penghuninya, serta dilengkapi prasarana sosial, ekonomi, budaya, dan pelayanan yang merupakan subsistem dari kota secara keseluruhan. Perumahan dan permukiman merupakan salah satu kebutuhan dasar manusia dan sistem penting dalam peningkatan harkat dan martabat manusia. Pemenuhan kebutuhan tersebut perlu keterlibatan semua pihak baik masyarakat, pengusaha dan pemerintah. Adanya ketidakselarasan masing- masing sektor di atas dapat memberikan dampak, yakni meluasnya lahan tidur di kawasan 
perkotaan, maraknya spekulan tanah, tidak seimbangnyapembangunan desa dan kota dan maraknya permasalahan sosial kemasyarakatan terutama di perkotaan serta tumbuhnya kawasan kumuh.

\section{Hunian Modular}

Istilah Arsitektur modular merupakan sebuah konsep pembangunan objek rancangan berdasarkan modul tertentu. Produksi modul yang dapat ditempuh melalui sistem fabrikasi dinilai mampu menekan waktu pelaksanaan pembangunan. Moshe Safdie berpendapat bahwa "a set of "requirements" which were essentially a set of criteria for space requirements and attributes necessary for one to lead a normal life, within a multi-unit apartment complex". Arsitektur modular berprinsip pada unit-unit modul yang mampu dibongkar pasang maupun ditambah serta dikurangi dengan mempertimbangkan mobilitas modul dari tempat produksi ke lahan rancangan sehingga mempermudah jalannnya proses kontruksi. Sistem ini menawarkan percepatan waktu serta kemudahan pemasangan, efisiensi dalam transportasi dengan produk yang tahan lama, yang berarti meningkatkan produktifitas. Hunian modular ini sangat berguna bagi individu, perusahaan dan lembaga pemerintahan yang memerlukan hunian atau fasilitas yang permanen maupun sementara.

\section{METODE}

Metode penelitian yang digunakan dalam penelitian ini adalah metode penelitian kuantitatif dengan jenis penelitian deskriptif. Teknik sampling yang digunakan dalam penelitian ini adalah convenience sampling, yaitu pengambilan sampel berdasarkan kesediaan responden untuk mengisi kuesioner (Gravetter \& Forzano, 2012). Data dikumpulkan dengan observasi dari fenomena-fenomena yang terjadi dan wawancara dengan pekerja generasi millennial

Metode perancangan yang digunakan dalam penelitian ini berdasarkan dari buku "Basics Design Methods" menggunakan Rationalist Approaches - Performance Form dinilai yang paling cocok dikarenakan fungsi dari bangunan sudah jelas yaitu berupa hunian, dengan begitu optimalisasi bentuk hunian dapat dimaksimalkan lebih baik. Dengan fungsi yang sudah terdefinisi dengan jelas maka dapat diperkirakan besar ruang, kenyamanan penggunaan, hingga biaya, sebagai acuan, desain diharapkan nantinya akan lebih efisien dan optimal sehingga cocok dengan kriteria hunian bagi kaum milenial yang ingin serba mudah dan fleksibel.

Penulis juga menggunakan penyusunan metode desain yang dilandasi oleh teori dari buku Architecture Programming oleh Donna P. Duerk, yang dalam bukunya menyebutkan bahwa "the process of managing information so that the right kind of information is available at the right stage of the design process and the best possible". Hal itu dapat diartikan sebagai tahapan dari proses desain dengan penelitian dan analisis mengenai desain tersebut sehingga dapat digunakan dalam proses desain untuk mencapai sebuah hasil yang tepat.

\section{DISKUSI DAN HASIL}

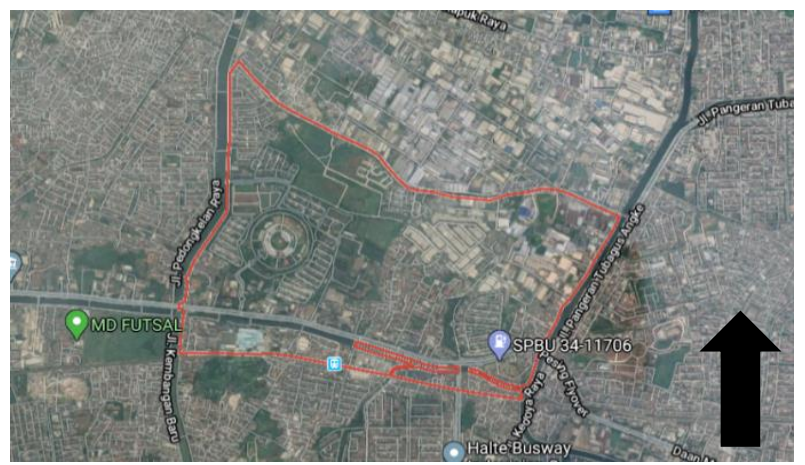

Gambar 1. Kelurahan Kedaung Kaliangke Sumber: https://www.google.com/maps 
Kecamatan Cengkareng merupakan salah satu kecamatan di wilayah Kota Administrasi Jakarta Barat, terdiri atas 6 kelurahan, 84 RW (Rukun Warga) dan 1.017 RT (Rukun Tetangga), memiliki jumlah penduduk sebanyak 514.416jiwa yang terdiri dari 262.093 Penduduk laki-laki dan 252.323 Penduduk perempuan dengan tingkat kepadatan penduduk sebesar $19.383 \mathrm{jiwa} / \mathrm{km}^{2}$. Cengkareng merupakan kecamatan di Daerah Khusus Ibukota Jakarta dengan populasi paling banyak. Menurut data Badan Pusat Statistik Jakarta, jumlah penduduk Cengkareng mencapai 494.660 jiwa atau 4,9 persen dari total populasi di Jakarta, yakni 10 juta jiwa pada 2014. Saat ini terdapat 44 kecamatan di Provinsi DKI Jakarta, termasuk Kepulauan Seribu Utara dan Kepulauan Seribu Selatan.

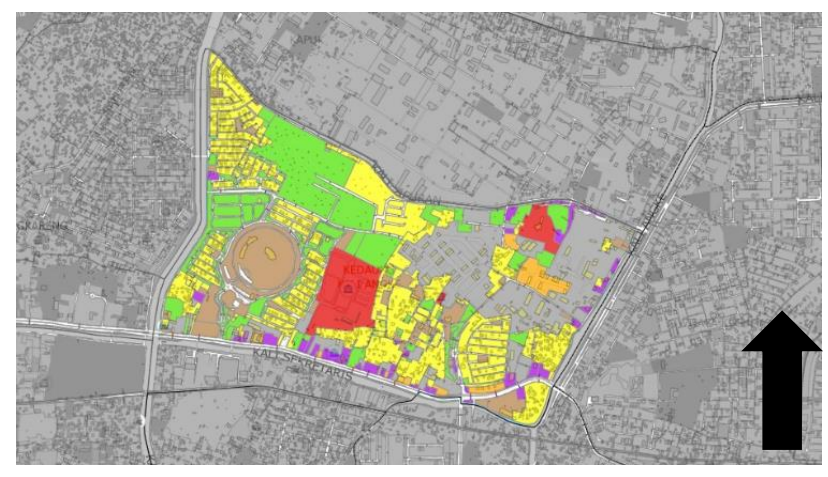

Gambar 2. Peta Penggunaan Lahan

Sumber: Jakarta Satu

Dapat dilihat dari penggunaan lahan di atas kawasan kelurahan Kedaung Kaliangke di dominasi zona permukiman dan Zona industry / pergudangan. Terjadi perbedaan kawasan permukiman mayoritas berada di perumahan cluster, dan pada sekitar tapak cenderung permukiman kumuh yang belum tertata dengan baik.

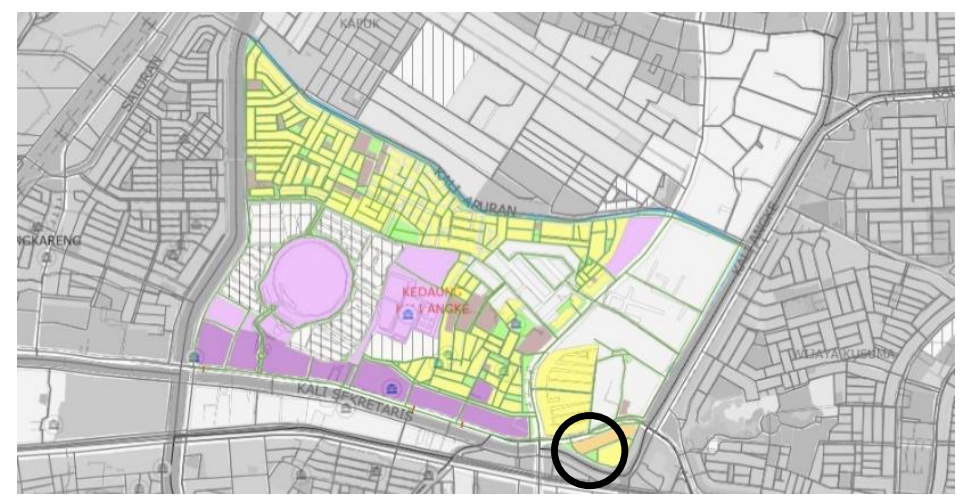

Gambar 3. Peta Rencana Kota

Sumber: Jakarta Satu

Berdasarkan dari rencana perkotaan sendiri terdapat perubahan pada rencana jalan kota di sekitar tapak, dan peruntukan pada Jalan Daan Mogot Rd akan di dominasi oleh zona perkantoran dan perdagangan, yang dimana sangat strategis untuk mendirikan hunian bagi kaum milenial untuk kedepannya. 


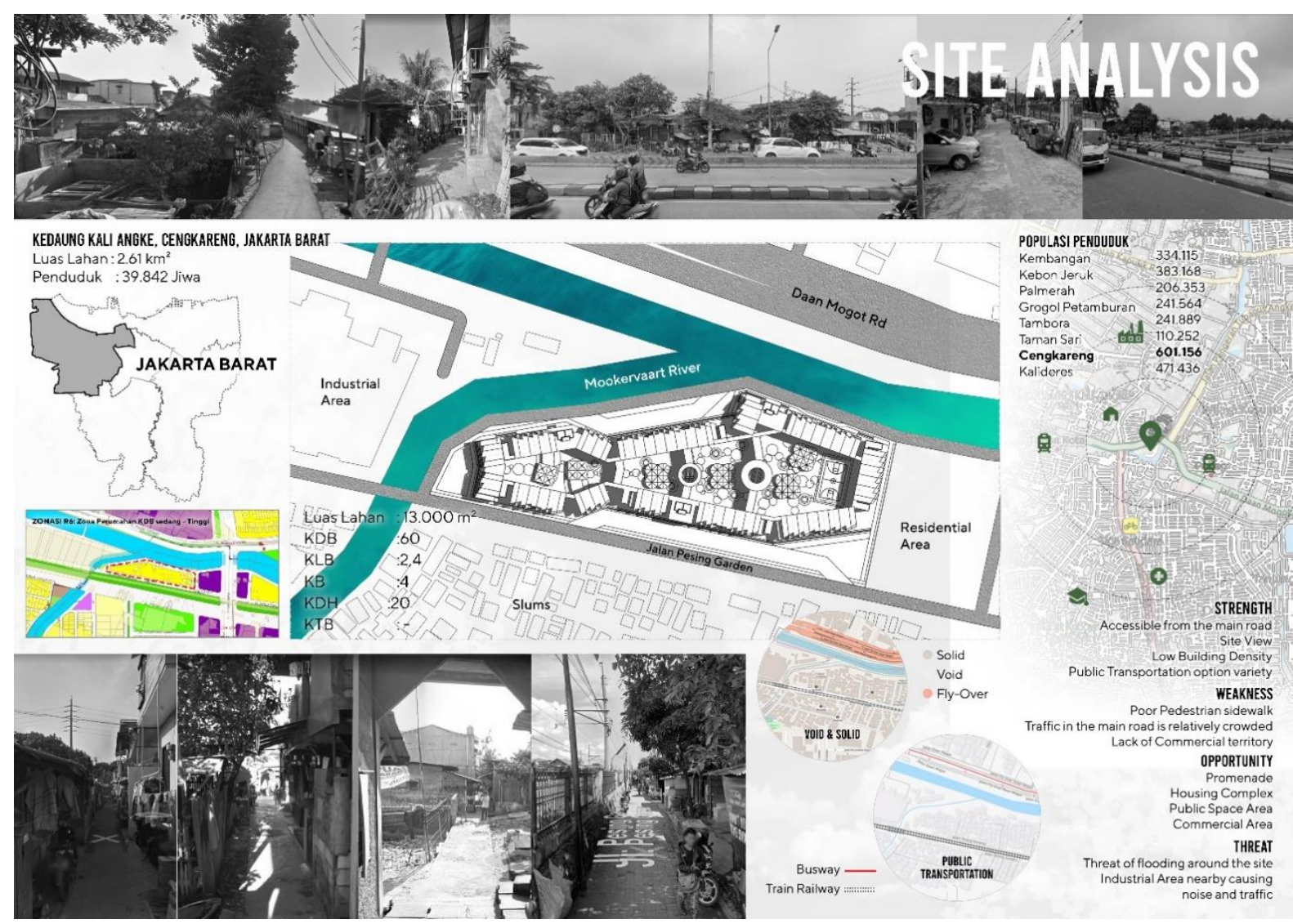

Gambar 4. Analisis Tapak

Sumber: Penulis, 2020

\section{Pemilihan Tapak}

Tapak terpilih berada di Jalan Daan Mogot. Alasan pemilihan tapak ini, kawasan ini didominasi oleh permukiman penduduk. Dari para penduduk yang tinggal disini, banyak yang bekerja di luar kawasan tersebut, sehingga, bagi mereka yang baru pulang atau hendak berangkat kerja, memungkinkan diposisikan hunian bagi para pekerja pada tapak ini. Permukiman penduduk yang padat di kawasan ini menyebabkan kurangnya ruang terbuka. Pemilihan tapak di daerah yang tidak terlalu padat ini memungkinkan untuk di ciptakan program baru yang memiliki ruang terbuka sehingga dapat menarik penghuni ataupun pengunjung ke tapak ini. Tapak bersebelahan langsung dengan permukiman warga, sekaligus berada di jalan yang dapat dilalui kendaraan umum. Tapak ini juga tidak jauh dari permukiman menengah dan permukiman kumuh. Saat ini, tapak dipergunakan sebagai tempat Pool Bus dan permukiman kumuh. 


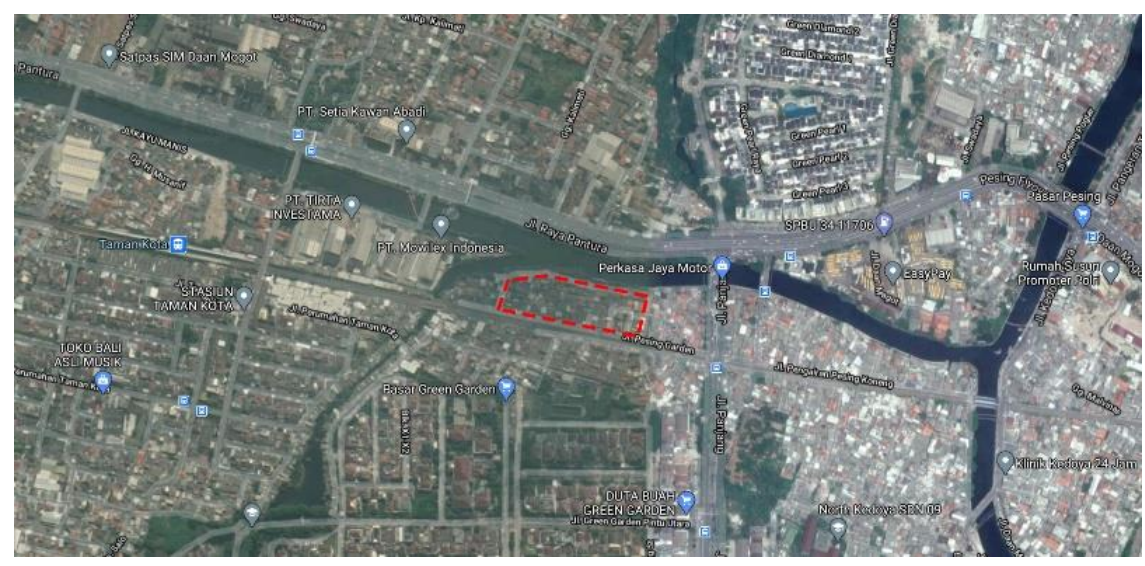

Gambar 5. Tapak terpilih

Sumber: https://www.google.com/maps

\section{Data Tapak}

Zonasi : Zona Perumahan KDB Sedang-Tinggi / R.6

Luas $: 13.000 \mathrm{~m}^{2}$

KDB $: 60 \%$

KLB $: 2,4$

$\mathrm{KB}: 4$

$\mathrm{KDH} \quad: 20 \%$

KTB :-

\section{Pendekatan Desain Arsitektur Modular}

Sistem modular pada unit hunian berupa modul fabrikasi dinilai mampu mempercepat pembangunan serta dapat menekan kebutuhan maintenence pada unit hunian. Terdapat dua jenis hunian berdasarkan tipe penghuni sehingga pada masing-masing hunian akan memiliki konfigurasi modul sendiri. Dapat terlihat dari suasana yang tercipta di dalam maupun di luar bangunan akibat dari konfigurasi modul pada masing-masing tipe unit hunian

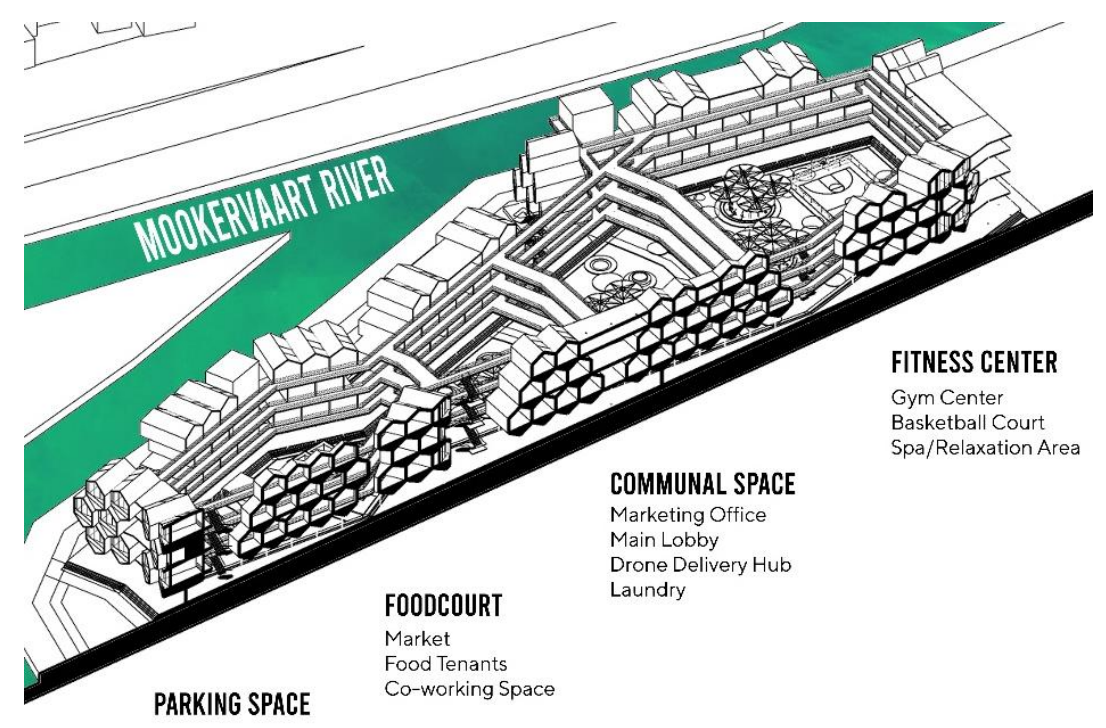

Gambar 6. Potongan Axonometri Modular Hunian

Sumber: Penulis, 2020

Dapat terlihat dari Gambar 6 memperlihatkan modul-modul yang disusun secara beraturan, memiliki rencana lantai yang tidak sama di setiap lantainya yang dikarenakan modul yang berbentuk hexagon. Konsep demikian menjunjung upaya memaksimalkan penghawaan dan pencahayaan alami yang masuk ke dalam ruang-ruang hunian. 


\section{Social Cohesion}

Pendekatan desain yang digunakan dengan orientasi kebiasan sasaran penghuni milenial. Seperti kebiasaan untuk berkumpul, bergotong royong dan melalukan aktivitas secara bersama-sama di luar aktivitas kerja menjadi bagian penting dalam upaya menghadirkan ruang-ruang publik dan fasilitas bersama disetiap lantai yang mampu dimanfaatkan secara komunal. Aktivitas penghuni didukung dengan adanya fasilitas publik yaitu area olahraga dan taman bermain di titik pusat keseluruhan tapak

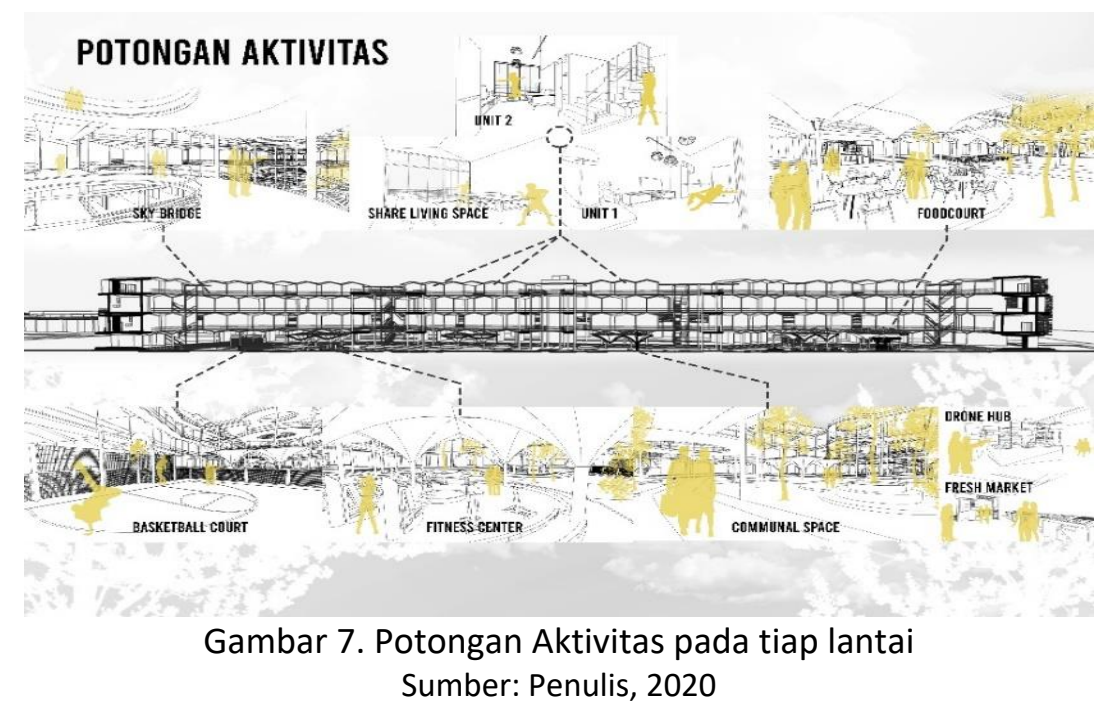

Pada Gambar menunjukan potongan aktivitas pada tiap lantainya, pada tiap program ruang memberikan kesan luas dan terbuka sehingga para penghuni dapat melaksanakan social distancing pada sekitar area hunian ini. Dan banyak tersedia ruang-ruang public yang dapat dimanfaatkan secara komunal sehingga akan menciptakan interaksi social antar penghuni.

\section{Modul Unit}

Bentukan awal modul berawal dari geometri hexagon, alasan menggunakan bentuk hexagon pada tampaknya yang dikarena penempatan modulnya akan memberikan fleksibilitas dalam penyusunan antar hunian dan fasilitas umum, sehingga memberikan konektivitas yang tidak monoton dan memberikan pengalaman ruang yang berbeda. Dikarenakan geometri hexagon membuat hunian antar lantai berbeda dan memiliki alur Zigzag pada tiap lantainya.

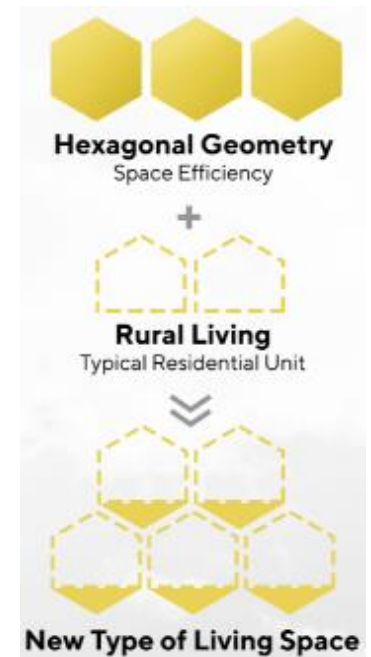

Gambar 8. Skema Massing Modul Unit Sumber: Penulis, 2020 
Lalu geometri hexagon pada modul tersebut digabungkan dengan tipologi Arsitektur Urban Village atau bisa disebut juga sebagai Rural Living dimana tipologi tersebut sering ditemukan di Indonesia pada perumahan di pedesaan, dengan begitu akan menciptakan kesan nature dan nyaman. Dan terciptalah tipologi hunian yang baru yang menyajikan fleksibilitas dan kenyamanan bagi para penghuninya, dan juga pada modulnya juga terdapat Sharing Living Space yang dapat digunakan bagi para penghuni sehingga menciptakan interaksi sosial bagi penghuninya.

\section{Zoning Tapak}

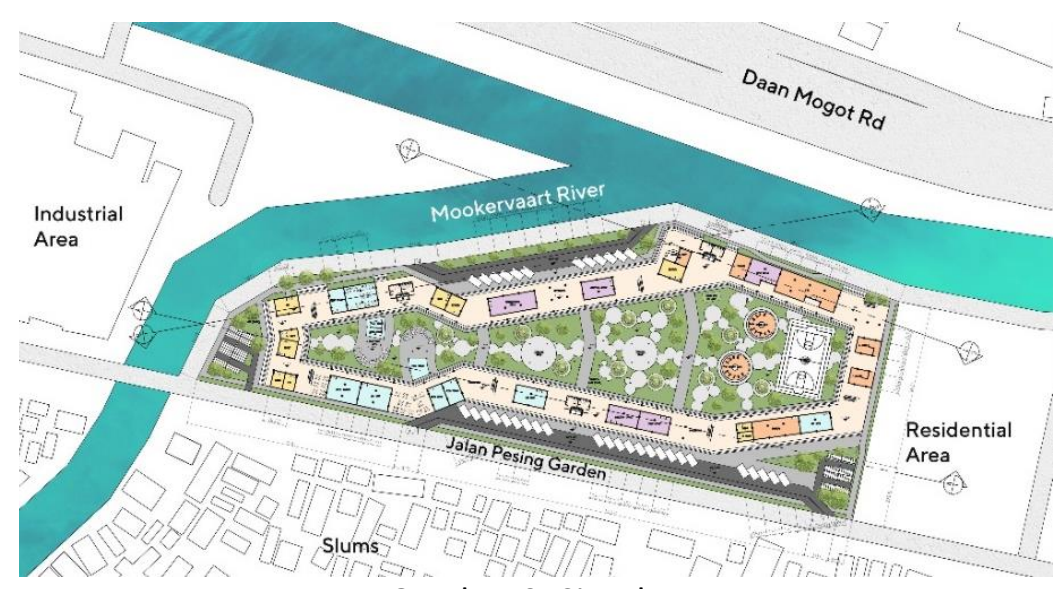

Gambar 9. Siteplan

Sumber: Penulis, 2020

Area pada siteplan dibagi menjadi tiga bagian, pada barat tapak terdapat area food and beverages dimana area ini menyediakan kebutuhan pangan para penghuni dan juga terdapat Co-Working Space, tambahan program tersebut untuk mewadahi para penghuni yang mayoritas pada kalangan produktif. Dan area ini terdapat area outdoor maupun indoor sehingga dapat mereduksi potensi penyebaran wabah penyakit yang sekarang ini sedang terjadi.

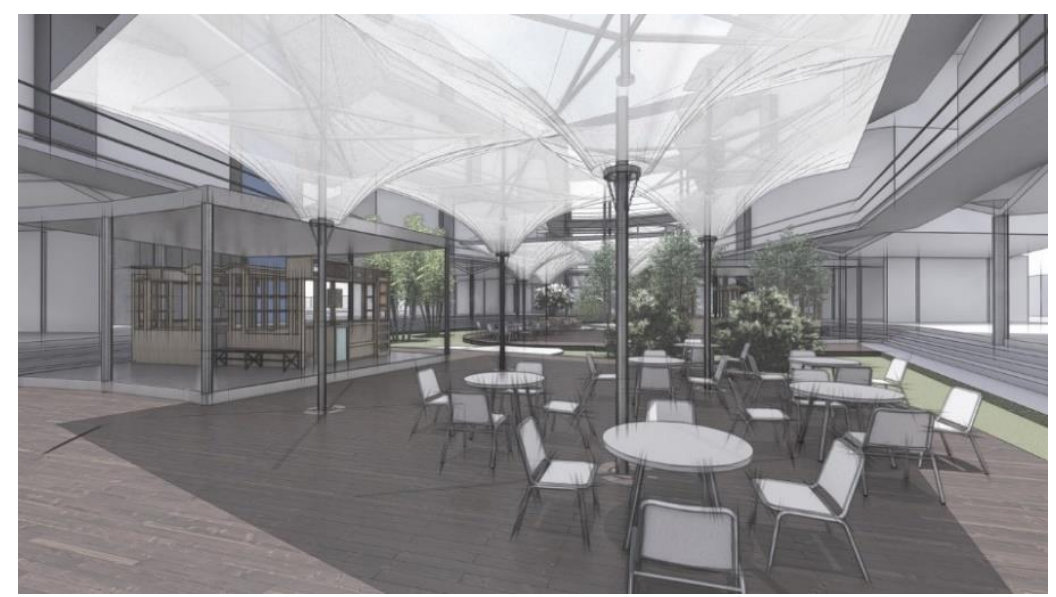

Gambar 10. Food and Beverages Area

Sumber: Penulis, 2020

Lalu Area kedua yaitu terletak pada tengah tapak dijadikan sebagai pusat komunal dimana para penghuni dapat berkumpul dan bersosialisasi, tidak hanya sebagai tempat berkumpul namun juga tersedia fasilitas umum layaknya seperti, Laundry dan Drone Delivery Hub. Diposisikan ruang komunal pada tengah tapak yang dikarenakan flow pejalan kakij bermula pada tengah tapak sehingga sangat strategis jika diletakan sebuah ruang komunal pada area tersebut. Nuansa pada ruang komunal memberikan kesan Nature dan Openess, dengan begitu para pejalan kaki yang melewati area ini akan merasakan pengalaman ruang yang baik dan nyaman. 


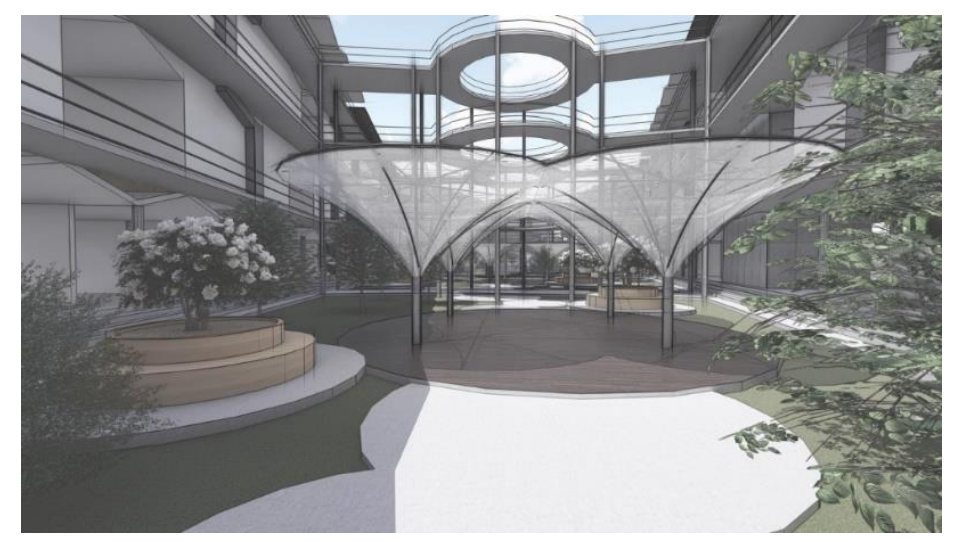

Gambar 11. Communal Space

Sumber: Penulis, 2020

Pada Area ketiga yaitu terletak pada timur tapak dijadikan sebagai pusat kebugaran dimana para penghuni dapat menggunakan fasilitas umum olahraga sehingga mendorong gerakan hidup sehat bagi para penghuninya. Pada Area ini terdapat Fitness Area, Basketball Court, dan Spa \& Relaxation Area.

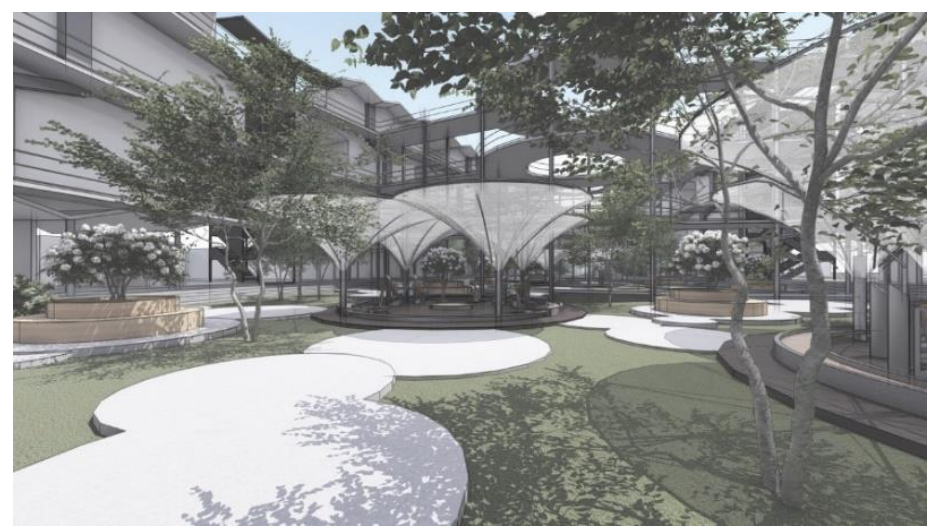

Gambar 12. Fitness Area

Sumber: Penulis, 2020

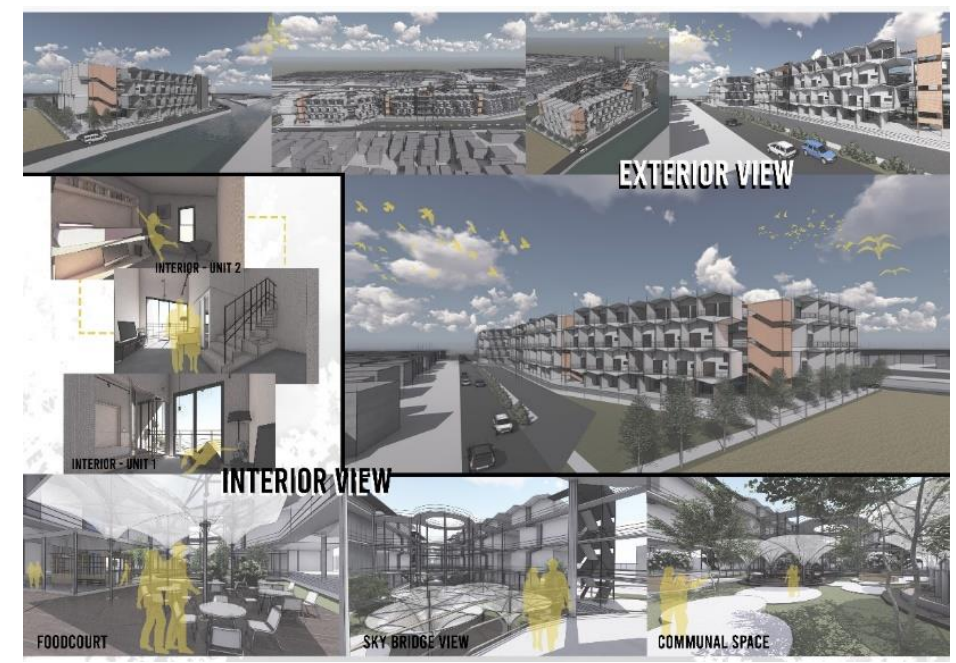

Gambar 13. Perspektif Eksterior dan Interior Sumber: Penulis, 2020 


\section{KESIMPULAN}

\section{Kesimpulan}

Proyek ini berusaha untuk memberikan wadah berupa hunian bagi kaum milenial yang kesulitan untuk mendapatkan hunian di tengah perkotaan. Dengan menghadirkan hunian yang compact dan efisien akan memenuhi segala kebutuhan ruang yang diinginkan para kaum milenial yang saat ini kesulitan untuk memiliki hunian di tengah perkotaan. Dengan hunian modular yang memiliki penempatan yang penuh dengan fleksibilitas serta menciptakan pengalaman ruang yang baru bagi para penghuninya, tidak hanya pada penempatannya namun juga pada segi interior hunian yang mampu berubah fungsi sehingga dapat beradaptasi dengan kebutuhan ruang para kaum milenial tanpa membuang ruang yang besar yang menyebabkan pemborosan ruang pada hunian. Menghadirkan hunian modul unit, dilengkapi dengan furnitur yang compact dan fleksibel sehingga meningkatkan efisiensi ruang pada hunian. Serta menghadirkan ruang bersama/ruang sosial contohnya seperti ruang kerja bersama, dapur bersama dan lain-lain, demi menciptakan ruang sosial bagi para penghuni, dengan begitu diharapkan mampu meningkatkan kualitas hidup kaum milenial.

\section{REFERENSI}

Duerk, D. P. (1993). Architectural Programming: Information Management for Design. New York : Van Nostrand Reinhold

Heidegger, M. (1962). Being and TIme Translated by John Macquarrie \& Edward Robinson. New York: Harper.

Heidegger, M. (1971). Building Dwelling Thinking. From Poetry, Language, Thought, translated by Albert Hofstadter. New York: Harper Colophon Books. http://home.lu.lv/ ruben/Building\%20Dwelling\%20Thinking.htm

Jormakka, K. (2008). Basic Design Method. Basel: Birkhäuser

Norberg-Schulz, C. (1985). The Concept of Dwelling: on the way to figurative architecture. New York : Rizzoli

Tschumi, B. (1994). Architecture and Disjuction. Cambridge: MIT Press.

Kementerian Pekerjaan Umum dan Perumahan Rakyat. 19 Juni 2019. "Kementerian PUPR Dorong Generasi Millenial Miliki Rumah", diakses pada 21 November 2020 pukul 16.34, https://perumahan.pu.go.id/ruk/index.php/berita/view/15157/kementerian-pupr-doronggenerasi-millenial-miliki-rumah

Mega Build Indonesia. Juni 22, 2020. "Mengenal Tren Hunian Co-Living yang Lebih Digemari Millennial", diakses pada 20 November 2020 pukul 10.30, dari https://www.megabuild.co.id/mengenal-tren-hunian-co-living-yang-lebih-digemari-millennial/

Suhaiela Bahfein. 28 Maret 2020. "Survei: Milenial Indonesia Lebih Mengincar Rumah ketimbang Apartemen", diakses pada 21 November 2020 pukul 15.45, https://properti.kompas.com/read/2020/03/28/130820321/survei-milenial-indonesia-lebihmengincar-rumah-ketimbang-apartemen 
